\title{
Amazing Grace: The Near-Death Experience as a Compensatory Gift
}

\author{
Kenneth Ring, Ph.D. \\ University of Connecticut
}

ABSTRACT: This paper illustrates the apparently providential timing and the healing character of near-death experiences (NDEs) and NDE-like episodes, through four case histories of persons whose lives, prior to their experiences, were marked by deep anguish and a sense of hopelessness. Spiritually, such case histories suggest the intervention of a guiding intelligence that confers a form of "amazing grace" on the recipient. Methodologically, these reports point to the importance of taking into account the person's life history as a context for understanding the full significance of NDEs and similar awakening experiences. The article ends with a retrospective account of a childhood NDE in which "the big secret" of these experiences is disclosed.

"We who are about to die demand a miracle."

W. H. Auden (cited in Grosso, 1985)

During the past fourteen years of my research on near-death experiences (NDEs), I have often been struck by the seemingly providential character and timing of these experiences. An individual whose life is spinning out of control and heading on a clearly self-destructive course has an accident and experiences the healing balm of absolute love and unconditional acceptance in the light, and returns to life knowing he has been set right again. A man, after several previous suicidal gestures, takes a massive overdose of barbiturates that would ordinarily guarantee his demise, but for some unknown reason an NDE super-

Kenneth Ring, Ph.D., is Professor of Psychology at the University of Connecticut. Reprint requests should be addressed to Dr. Ring at the Department of Psychology, University of Connecticut, Storrs, CT 06269-1020. 
venes, during which he comes to see his life with the healing clarity of deep compassion and self-understanding. He hears a telepathic communication-he knows not from whom-telling him that he will recover and will never again attempt suicide, and so it is. A woman, the victim of childhood incest of which she has no conscious memory, falls seriously ill with an undiagnosed illness and while close to death has a fullblown NDE during which she remembers. The unlocking of her poisoned memories unleashes powerful healing energies and enables her to confront for the first time and eventually to overcome the psychological obstacles that had hitherto crippled her life.

When such cases as these-and they are typical of many NDErs I have encountered-are considered one after another, it is hard to resist the inference that the NDE, at bottom, is itself $a$ healing force. It is almost as though some guiding and benevolent intelligence, seeing that a person's life is about to be shattered, intervenes at the critical moment and makes it whole again (healing of course means "to make whole") by providing a soul-saving revelation through the NDE.

\section{Amazing Grace}

Recently, I came across this same dynamic operating in a different developmental context. In some research by Christopher Rosing and myself (Ring and Rosing, 1990), we discovered that NDErs are disproportionately likely to come from the ranks of children who had been abused or had experienced other forms of trauma or stress in childhood. Musing on the possible psychosocial roots of the NDE, it occurred to me that in some strange, and strangely comforting, way the NDE may sometimes be almost like a compensatory gift vouchsafed to those who have had to endure the terrible wounds of such childhoods. In these cases, the NDE - as the data from our study suggested-appears to confer both a heightened sense of compassion and an extended range of intuitive perception that together help the individual gain a compensatory edge in coping with and understanding life's difficulties. Furthermore, it seems probable that the spiritual qualities so evident in and so evidently valued by so many NDErs-and which again our research, and that of others, has consistently disclosed-would not have emerged without the stimulus of the NDE itself.

Finally, I must mention another recent source of these reflections on the remarkable healing potential of NDEs. In the last year or so, I have received a number of written accounts of such experiences that I count as among the most extraordinary and deeply moving of any I have 
amassed over the past fourteen years. Why I should be the recipient of such a treasury of inspirational documents of this sort in such a relatively short time is a bit of a conundrum, but not one that I intend to try to solve here. Instead, I would simply like to share them with you here in order to illustrate my thesis with these stories of exceptional worth and emotional compellingness, for these testimonies have a great deal to teach us about what I regard as the almost providential character and timing of these experiences.

Thus, the chief purpose of this article is to present in full some of the richest instances of NDEs and kindred experiences that I have encountered in nearly a decade and a half of near-death research. In addition to their implications for a kind of benign, higher-order intervention, a couple of them represent instances of something exceedingly rare in the near-death literature: essentially complete NDEs in which the full compass and meaning of the near-death journey are unmistakably revealed. Because most published NDEs are really nothing more than isolated fragments of a person's experience, we tend to overlook the fact that NDEs occur within the context of a person's entire life and that their full meaning can only be understood in that context. For that reason, with one exception I will reproduce the accounts in full so that what you will be reading is effectively the writer's own story within which the NDE can be seen in its appropriate life context. Not all of these experiences may be, strictly speaking, NDEs, but they all share the same essential qualities that will be evident to anyone familiar with the literature on this subject. Needless to say, I am greatly indebted to the writers of these documents for their permission to reproduce them here and for their permission to use their real names.

\section{Beverly Brodsky}

In August, 1990, I attended the International Association for NearDeath Studies (LANDS) International Conference in Washington, DC. The turnout was large and I was delighted to see many old friends there, professional colleagues and NDErs alike. One morning, having arranged to have breakfast with about a half dozen persons whom I didn't previously know, I sat down and began to listen to an ongoing conversation between two early arrivals. I was particularly struck by the woman of the pair. Small, slender, and dark-skinned, she spoke intently and with a tone of great seriousness about her own experience. Frankly, I was more aware of her manner of speaking than of the 
content of her conversation, but since the other members of our party arrived shortly thereafter, it was impossible for me to hear much about her experience, as our breakfast table discussion soon ventured into other realms of especial interest to me. Nevertheless, I made a point of tracking down this woman, Beverly Brodsky, later that day and endeavored to find out a little more about her life, since she had captured my interest so forcibly. We had time only for a short chat before I needed to leave for another engagement, but even without having heard any more of the story of her NDE, I knew that I wanted to learn more about it. Before I left, I asked her whether she would be willing to write out a version of it for my files.

A few days later, she sent the following document to my office:

I was raised in a nonobservant Conservative Jewish family in an overwhelmingly Jewish neighborhood in Philadelphia. The atmosphere was materialistic and, for me, claustrophobic. In high school girls were judged by their clothes and beauty. Bookish, shy, and serious, I went through my teens as an atheist. Since learning, in very muted terms, of the Holocaust at age $8 \mathrm{I}$ had turned angrily against any early belief in God. How could God exist and permit such a thing to occur? The secularism of my public school education and the lack of any religious training added fuel to my beliefs.

I went through a period of depression growing up that was not treated, due to my parents' unfortunate adherence to the belief that psychological treatment was disgraceful, and that personal problems or family secrets should never be aired outside the home. I had reached a desperate phase upon graduating from high school. Too upset to go to college despite my brilliant academic performance, I had trouble facing the future. To make things worse, shortly after graduation, at age 17, my father died suddenly from a heart attack. He had been my rock, my strength, in this world.

My mother went through an emotional crisis of her own after this loss, simultaneously entering menopause. No longer able to bear this unhappy environment, I left home at age 19, living first in Philadelphia's center city, and later moving out to California, where people then wore flowers in their hair and spoke of peace and love for all mankind. I had learned to meditate and for the first time had some hope that I could start over. To me the journey out West was like Hesse's "Journey to the East"-a quest for a new world.

In July, 1970, I suffered a fractured skull and numerous broken bones in my head due to a motorcycle accident that occurred in Los Angeles, California. I had just arrived in California the day before. The motorcycle ride, my first, was part of the celebration of arrival; we were returning from seeing the play, "Hair." I was a passenger on a small highway where helmets were not required, and was struck by a drunken driver. I was thrown to the ground headfirst. When the police arrived, they initially took one look at me and started to book the driver of the car on manslaughter charges since my head was so badly mangled. 
I spent two weeks in the hospital, where my fracture was sutured and I was given morphine for the pain. Then I was sent home and told to take aspirin. Since my pain threshold has always been very low, and my selfimage was shattered by the contusions which had torn off half the skin from my face, I went home to my temporary apartment with the firm intent that the first night home would be my last. I lay down on the bed and, becoming an agnostic in this moment of trial, as many atheists do, prayed fervently for God to take me; I could not live another day. At 20 I had no goals but to enjoy life and find someone to share it with. The pain was unbearable; no man would ever love me; there was, for me, no reason to continue living.

Somehow an unexpected peace descended upon me. I found myself floating on the ceiling over the bed looking down at my unconscious body. I barely had time to realize the glorious strangeness of the situation-that I was me but not in my body-when I was joined by a radiant being bathed in a shimmering white glow. Like myself, this being flew but had no wings. I felt a reverent awe when I turned to him; this was no ordinary angel or spirit, but he had been sent to deliver me. Such love and gentleness emanated from his being that I felt that I was in the presence of the messiah.

Whoever he was, his presence deepened my serenity and awakened a feeling of joy as I recognized my companion. Gently he took my hand and we flew right through the window. I felt no surprise at my ability to do this. In this wondrous presence, everything was as it should be.

Beneath us lay the beautiful Pacific Ocean, over which I had excitedly watched the sun set when I had first arrived. But my attention was now directed upward, where there was a large opening leading to a circular path. Although it seemed to be deep and far to the end, a white light shone through and poured out into the gloom to the other side where the opening beckoned. It was the most brilliant light I had ever seen, although I didn't realize how much of its glory was veiled from the outside. The path was angled upward, obliquely, to the right. Now, still hand in hand with the angel, I was led into the opening of the small, dark passageway.

I then remember traveling a long distance upward toward the light. I believe that I was moving very fast, but this entire realm seemed to be outside of time. Finally, I reached my destination. It was only when I emerged from the other end that I realized that I was no longer accompanied by the being who had brought me there. But I wasn't alone. There, before me, was the living presence of the Light. Within it I sensed an all-pervading intelligence, wisdom, compassion, love, and truth. There was neither form nor sex to this perfect Being. It, which I shall in the future call $\mathrm{He}$, in keeping with our commonly accepted syntax, contained everything, as white light contains all the colors of a rainbow when penetrating a prism. And deep within me came an instant and wondrous recognition: I, even I, was facing God.

I immediately lashed out at Him with all the questions I had ever wondered about; all the injustices I had seen in the physical world. I don't know if I did this deliberately, but I discovered that God knows all your thoughts immediately and responds telepathically. My mind was naked; 
in fact, I became pure mind. The ethereal body which I had traveled in through the tunnel seemed to be no more; it was just my personal intelligence confronting that Universal Mind, which clothed itself in a glorious, living light that was more felt than seen since no eye could absorb its splendor.

I don't recall the exact content of our discussion; in the process of return the insights that came so clearly and fully in Heaven were not brought back with me to Earth. I'm sure that I asked the question that had been plaguing me since childhood about the sufferings of my people. I do remember this: there was a reason for everything that happened, no matter how awful it appeared in the physical realm. And within myself, as I was given the answer, my own awakening mind now responded in the same manner: "Of course," I would think, "I already know that. How could I ever have forgotten!" Indeed it appears that all that happens is for a purpose, and that purpose is already known to our eternal self.

In time the questions ceased, because I suddenly was filled with all the Being's wisdom. I was given more than just the answers to my questions; all knowledge unfolded to me, like the instant blossoming of an infinite number of flowers all at once. I was filled with God's knowledge, and in that precious aspect of his Beingness, I was one with him. But my journey of discovery was just beginning.

Now I was treated to an extraordinary voyage through the universe. Instantly we traveled to the center of stars being born, supernovas exploding, and many other glorious celestial events for which I have no name. The impression I have now of this trip is that it felt like the universe is all one grand object woven from the same fabric. Space and time are illusions that hold us to our plane; out there all is present simultaneously. I was a passenger on a Divine spaceship in which the Creator showed me the fullness and beauty of all of his Creation.

The last thing that I saw before all external vision ended was a glorious fire-the core and center of a marvelous star. Perhaps this was a symbol for the blessing that was now to come to me. Everything faded except for a richly full void in which That and I encompassed All that is. Here I experienced, in ineffable magnificence, communion with the Light Be-

-- ing. Now I was filled with not just all knowledge, but also with all love. It was as if the Light were poured in and through me. I was God's object of adoration; and from His/our love I drew life and joy beyond imagining. My being was transformed; my delusions, sins, and guilt were forgiven and purged without asking; and now I was Love, primal Being, and bliss. And, in some sense, I remain there, for Eternity. Such a union cannot be broken. It always was, is, and shall be.

Suddenly, not knowing how or why, I returned to my broken body. But miraculously, I brought back the love and the joy. I was filled with an ecstasy beyond my wildest dreams. Here, in my body, the pain had all been removed. I was still enthralled by a boundless delight. For the next two months I remained in this state, oblivious to any pain. I wonder now if this were not the purpose behind the experience-to enable me to get through this period of recovery.

I felt now as if I had been made anew. I saw wondrous meanings everywhere; everything was alive and full of energy and intelligence. My 
sister, who visited me shortly after the accident, tells me that I once took her down to the ocean's edge, pointed up to the sky, and tried to show her the path that was inscribed there. She thought that I was either mad or on drugs!

I don't remember too much of this period, except that I did some things that were, for me, incredible. In the past I had been painfully shy and had felt myself unworthy of being loved. I went out, my head swathed in bandages like a creature from a horror film, landed a job in one week, made many friends, and got involved in my first serious romantic relationship. After the earthquake in 1971, I moved back East, went home to my mother, with whom I became reconciled, and started college at 23, another thing I never thought I could handle, and graduated Phi Beta Kappa. Since then I have married, become a mother, pursued a career, and have sipped deeply from the cup of life's blessings that I had never believed would come my way in those dark years before I found the Light. In that encounter with death, I was given joy and purpose to continue on with life.

Although it's been twenty years since my heavenly voyage, I have never forgotten it. Nor have I, in the face of ridicule and disbelief, ever doubted its reality. Nothing that intense and life-changing could possibly have been a dream or hallucination. To the contrary, I consider the rest of my life to be a passing fantasy, a brief dream, that will end when I again awaken in the permanent presence of that giver of life and bliss.

For those who grieve or fear, I assure you of this: there is no death, nor does love ever end. And remember also that we are aspects of the one perfect whole, and as such are part of God, and of each other. Someday you who are reading this and $I$ will be together in light, love, and unending bliss.

\section{Lorna Stephens}

At the same conference where I had met Beverly, I was asked to be the emcee for the Saturday night banquet which featured a talk by Raymond Moody on his latest interest, the ancient art of scrying or crystal-ball gazing. At the end of the banquet, a number of persons from the audience gathered around the head table, hoping to speak to some of the various presenters, and we all did our best to oblige them. However, time constraints and other post-banquet plans prevented us from talking to everyone, and, again, there was one woman who had been very persistent in wanting to talk with me whom I especially took note of and to whom I gave my sincere regrets for having no more time that evening. "Maybe tomorrow," I mumbled apologetically, knowing in my heart that tomorrow's schedule for me was even more crammed than Saturday's had been.

Three days after Beverly's letter had been sent, Lorna wrote hers- 
this time unsolicited-to me. Reading it, it was obvious that she, too, had been a recipient of amazing grace. It began:

Dear Dr. Ring,

My name is Lorna Stephens. I don't know if you'll remember me, but I was the "pest" at the IANDS conference last week. I wanted very much to speak with you, but there were so many, many people that needed to speak with you and I was heartfelt for them. I was kind of hoping that maybe someday you would be in Detroit and get in touch with me, but I can't wait for that, I guess. I need to tell you my NDE, but I also feel you need to hear it. I think it pertains to your research concerning NDEs and child abuse victims. I have been an experiencer in both. I need to begin at the very start so this may run kind of long, but I think it is important for you to know all details.

When I was a little girl-the youngest in my family-my earliest memory is my father waking up my older brother at night and beating him. I was about three and I can still hear Stephen (my brother) screaming for help. When I was little, Stephen always watched me. He was more like my father than my brother. My father should never have had children. He can't take noise.

Stephen took the blame many, many times for things I had done. One time when I was little, Stephen and I were in a store in a city where we were visiting relatives. It had this gold film on the windows. I couldn't have been more than four years old at the time, but as the sunlight shone through those windows I felt like I knew this warm and beautiful lightit was a feeling of deep love.

When I was six years old, Stephen started to abuse me sexually. It was to be a secret. And I never told anyone until years later. I, of course, couldn't understand why at times he loved me so much - and at the same time he would hurt me so bad. The sexual abuse continued until I was sixteen and finally strong enough to push him away from me. All during those years, though, I witnessed Stephen, my mother, and other members of my family being both physically and mentally abused. My father was a tyrant and seemed to want to abuse everyone but me. I had terrible feelings of guilt. And I grew up in what seems now as total fear and confusion.

When I was about six or so, I began to have the experience of déjà vu. But it was not so much that I felt I was here before. I knew that what I was doing, I had seen myself doing it before in my mind. I learned-well, I actually taught myself how to do this. I would just stare at an object and become deep in thought, just like Dr. Moody spoke of crystals and seeing, [and] would have flashes of future events. But they never really had any significance, but they did seem to happen at turning points in my life. Soon I learned that Stephen and I had a connection. It seemed we could tell what the other was thinking. I know this will sound very strange, but even though he was my abuser, as a young person I was very, very close to him. I just bottled the abuse part up inside of me and kept it there.

One day when I was about seven or eight years old, I was sitting in class and staring at a desk. I had flashes of a man in a studio with 
microphones and lots of buttons. All of a sudden, Stephen was yelling, "Lorna, Lorna, wake up." He had come to pick me up from my school class and walk me home.

As the years went by, Stephen and I became closer and closer. I loved him, I just hated the abuse. When we were teenagers we would go out together when neither of us had a date. We always had a lot of fun. He would always seem to forget birthdays and Christmas, so he would give you presents in between those times. He would take me shopping, just to look, and if I saw something that I liked, he would buy it for me. He really loved me. I don't think he ever wanted to hurt me.

When I was seventeen, my mom and I were talking about my father and all the terrible things he had done. I still remember the terrible guilt my mother showed in her face. I felt very sorry for her. Then she finally told me that my father had sexually abused my sister. It finally became clear why Stephen had done what he had done. It was what he had learned from my father.

A year later, when I was eighteen, I married a man who was very abusive as well. I was still too young to realize that I was marrying someone like my father. Stephen was very upset that I was marrying this man. All hell broke loose between us. We were no longer close. I got married and two years later had a little girl, and two years after that I had a little boy. My marriage was falling apart. My husband was into drugs and was physically abusing me. He was also seeing many women on the side. I acted like nothing was wrong, but Stephen knew.

I had a part-time job as an aerobics instructor at the YMCA. I had hardly any money. My husband was spending everything we had on cocaine (crack), women, and booze. I dealt with the bill collectors and my phone, gas, and electricity being turned off, not to mention two small children, the worries of how to feed them, and all of the physical and mental abuse.

As time went on I began to realize that Stephen was right. I also began to heal the wounds from my childhood even though I was still dealing with abuse. I had always had what I felt as a close relationship with God. I talked all the time to Him as a child, and always felt He was there for me. I began to forgive Stephen and had verbalized this to my best friend, Tina, who knew all about the abuse. She said she couldn't understand how I could forgive something like that and I couldn't explain it either, except that I had always loved Stephen and he was the only father I had ever had.

My mother and I were together one day talking and after a while we both admitted that we had strange feelings someone close to us was going to die. I began to have strange dreams after that. I had a dream that I was running through a woods, and I felt like something was chasing me, or I was chasing something-I'm not sure which. All of a sudden in the middle of the forest was a log cabin. I ran inside it and directly opposite the door I ran in was another door. There was darkness all around me inside this log cabin, but outside the other door was this incredibly beautiful meadow with flowers like I had never seen before. It looked so inviting but I knew that if I went through that door I could never go back. Then I woke up. 
Stephen had gotten married and moved to Madison, Wisconsin. I knew he was having problems. His wife had been married before and they were in a battle with her ex-husband for custody of her children. Stephen had become a truck driver and was very happy, but he wanted to father those children. I didn't know how to feel about that, but it seemed he had grown as a person, so I hoped it would be all right. Stephen's wife's exhusband hated Stephen, and had threatened to kill him. It turned out that Stephen's wife's ex-husband wanted to keep the children. He was sexually abusing the little girl. I think Stephen wanted that little girl so he could raise her with no abuse, to make up for me, his first little girl. (He really was more of a father to me than anything else.)

I only heard bits and pieces of this from my mom and small conversations I had with Stephen on the phone. I was back in Michigan with my own battles. My marriage was coming to an end and I knew it. Shortly after Christmas in January, 1986, I had taken back Christmas presents that had been given to me - to have money for shoes my children needed. That night when I came home and went to sleep, I had a dream that I was standing outside in the dark between what looked like trucks. It was a parking lot, I think. There were puddles on the ground and I looked up to see a figure standing in front of me, but in the distance. I saw the figure raise his arm and then I saw the barrel of a gun. I knew he was going to shoot me. He fired, and I felt the bullet hit me. I fell to the ground and then I was across the parking lot looking at my body and I saw a greenI'll be honest, I don't know how to describe it. It glowed and was shaped like a skeleton. It was rising out of my body. I woke up with a start and sat up in bed. I was in a cold sweat and very shaken.

The next day I spoke to Stephen on the phone. He said he had the feeling I was in too deep with something and that he just had the feeling that something very wrong was happening in my life. I lied and said that everything was fine. I asked him how he was and he said, "If you only knew what was going on in my life." I wanted so much to forgive him, to say I loved him and tell him I missed him, because I did. I really missed him. I really felt at peace about all that happened between us and I wanted to make up, but somehow it just didn't seem appropriate over the phone. We said goodbye and hung up.

In February, my mom called me [and] said that Stephen had left with his truck but had been missing for four days. She was very upset. I didn't know what to tell her, but not to worry. I said he probably was just busy on his run and hadn't gotten the chance to call. She said no, that he always called his wife and [she] hadn't heard from him and the trucking company he was working for didn't know where he was. I tried to assure her that everything would be all right. I went to work that night at the YMCA, and I feel guilty to say this, but I wasn't worried about Stephen.

The next morning the phone rang. My husband answered it. I heard him saying, "You're kidding" and "Oh, no." I thought Stephen had been hurt. My husband handed me the phone. He said it was my mother. I took the phone and said, "Hi, mom." She said, "Stephen is dead." I said, "What?" I couldn't believe my ears. She kept repeating, "Stephen is dead." We both began to sob. They found Stephen in the back of his cab. He had never left the truck stop in Wisconsin to his run down south. 
They did an autopsy. I received a copy and it's full of contradictions. They never ruled out foul play and a lawyer told my mom to have a second autopsy done, but by that time it was too late-he had already been cremated.

We went through the funeral and I was devastated. Stephen's birthday was February 22, twenty days after his death (he would have been 31 ). We, as a family, decided to get together at my sister's house in Ann Arbor for his birthday. It was very sad. I baked a cake, even, and covered it with jelly beans (they were his favorite thing to eat). When I got to my sister's she had pulled out all those pictures from our childhood that my mother had sent her when she lived in England. (She lived in England for some years when I was a child to get away from my father.) I had never seen most of those pictures. And many of them were of Stephen and me. They brought back memories that I hadn't had in years. Happy memories of the good times he and I had shared, and there were so many. It was my life in review. I became so sad.

I drove home that evening. My husband was in bed asleep, and I wanted-I really wanted to die. Dr. Ring, I was dying inside-dying of a broken heart. I fell on my couch, and as I fell, I started to rise up. I was floating up to the ceiling and then it was like a broken TV screen, a bad signal. Suddenly I saw I was floating in space, but it wasn't like a night sky because the stars were colored and iridescent looking. In the middle of this was a loaf of bread. I know that sounds strange, but it wasn't like a loaf of bread you'd find in a grocery store. It was like homemade bread or a loaf of bread that they would use in church for communion.

All at once I was inside this bread and it was filled with light. Bright, white light, yet soft and easy to look at. It was like the light was alive. And I felt like I was being embraced. Hugged.

Standing in front of me was Stephen. And between us was a windowwell, really a hole that looked out to the iridescent stars. He had the same stars in his eyes. He was dressed just like he always had, in blue jeans and a plaid flannel shirt. He looked like Stephen always looked, except for the stars in his eyes. He spoke to me, but he didn't use words. I mean he didn't talk. I just heard him in my head. He said he knew all that I was feeling and that I forgave him and that he forgave me, too. He said he loved me and not to worry about him. Then he said some things I don't remember. But the last thing he said was that when the time came he would meet me there.

All of a sudden, I was falling back, not fast like falling off a cliff or something, but very gently. And then, and I know this sounds strange, I was in my living room looking at my body on the couch from across the room-and then, snap, I was back in my body. I got up from the couch, and even though all that had happened, I didn't feel shocked or surprised, but drained. And I went to bed. (This was not a dream. I would know if it was a dream. I wasn't asleep.)

After this I still felt very sad and missed him very much. About six months later I was supposed to be going to a meeting of instructors at the YMCA, but I was sad and missing Stephen. I just couldn't go. I found myself driving by an old graveyard we used to think was really neat when we were kids. It has old tombstones from one hundred or so years 
ago. I got out of my car and started walking through this graveyard. It was a warm, sunny, summer day, but I felt like it should have been raining. Suddenly, a thought popped into my head-"John 6." I wasn't thinking about anything like that. I had gotten away from going to church, but "John 6" kept popping into my head.

For a week after this, it kept coming to me. Finally I thought, "Sit down and read this." I read it and in it, it says, "I am the bread of Life and all who believe in me shall not die, but have eternal life." And then I thought: "So that's the bread!" That's what the bread meant.

About two months after this I was at a friend's house who knew Stephen. We were talking about old times we all shared together. I had mentioned to her how my mom wished I would go back to church. She said, "Well, why don't you go and surprise her?" It was about 2 a.m. Sunday morning when we were talking. I said to her, "Yes, I should."

So I went home and got a couple hours sleep and then went to the church. I got there before my mom. She was very surprised to see me. She went downstairs where she teaches Sunday school. I went into the Sanctuary. As I went in, someone handed me a program, and on the cover was a picture of my loaf of bread! Just like I had seen it. And about it, it said, "That you may Live ..." I started to cry. I went in the church and sat down. It so happened that they were having communion that day. As the minister gave out the communion, he said, "I am the bread of Life, and all those who believe in me shall not die, but have eternal life." Well, you can imagine how astounded I was.

Since that time I did nothing but search for something. At the time I didn't know what to look for. I went to the library and looked up a book on astral projection. On the cover of it was the green glowing skeletonshaped thing I saw in my dream. (I had never seen this book before.) I didn't find anything I wanted in that book, though. Then I found Life After Life by Raymond Moody [1975]. I loved it, but I only wanted to read more-and I kept reading anything I could on NDEs.

I divorced my husband. Went to school for broadcasting (something I had always wanted to do). Met my fiancé (he was one of my teachers).

I kept looking for NDE books. After a few years I got a job at a radio station. One day when a basketball game was being broadcast and I didn't have to do any reports, I went to a nearby bookstore (this was last April). I saw a book called Full Circle by Barbara Harris (Harris and Bascom, 1990]. I loved it. At the end she mentioned IANDS. And also the conference in August. I knew I was going.

The next day I was talking to a friend I work with about it and suddenly realized it was what I saw as a little girl - the man in the studio with microphones and all of our buttons. I know now my whole life has led to this.

I bought Life at Death [Ring, 1980] and Heading Toward Omega [Ring, 1984], and I'm still reading the latter. When I saw you at the conference, I recognized you at once. I hope I have given you something. I feel a Love for you, Dr. Ring, and hope someday you'll say, "Call me Ken." I've pestered you enough and hope maybe someday we'll be able to talk. I don't know where all this is taking me next, but I have never been happier. I'm getting married again next April thirteenth. He, the man 
that I'm marrying, knows this story, my story, and loves me unconditionally and supports me. His name is Vaughn. My name again is Lorna, but you can always call me "Pest." I Love you.

P.S. I find it interesting that Vaughn was born dead.

\section{Pat Clark}

My friend Diane Norton deserves an article - if not an entire book -in her own right, but here I want to introduce a friend of Diane's, Pat Clark. Before I heard directly from Pat, I had learned from Diane that Pat was no mere friend. Instead, for Diane, Pat was a spiritual twin, and the only person that Diane had ever found whose pre-NDE experiences had matched her own. For some months before I actually received a letter from Pat, Diane had alerted me that Pat was intending to write me at length, but would do so only "when the time was right." One day, it was.

Dear Dr. Ring,

$\mathrm{Hi}$; my name is Pat Clark and because you are into NDEs I am writing you this letter to tell you some things about myself and my near-death experience.

First and foremost, it has taken me a while to write you, for the timing wasn't right until now. For some unknown reason, as a lot of things since my NDE are unknown, I had to wait at least a year after my NDE to tell you about it.

Let me begin by giving you some background information, and as you will read, being near death spanned a number of years of endless adventures, resulting in the fact that the timing was not there for me to die for any amount of time. Again the timing of events in my life, anyway, are and have been an important factor, just like I mentioned before about the timing of this letter-it wasn't meant to be until now.

I'm thirty-five years old. For the past twenty-three years I used and abused drugs. At the age of 12 my mother died and I had a breakdown. I was given Librium to calm the nerves and calm I stayed, for a while anyway. The following year my family doctor gave me Darvon for cramps. At fourteen I started with illegal drugs in a life that spanned the next twenty-one years. Abusing at that time everything from crystal Methedrine (speed) to different and colorful acid, including LSD, orange sunshine, purple ozziline, white lightning, windowpane, and mescaline. I'd like to point out that during this era in my life, hallucinations were an everyday thing. Illusions, hallucinations, and dimensional warps were one thing. My NDE was another.

I feel very strongly on this because there is a big difference in that when I took acid, the acid caused the events of seeing things and you have a sense of knowing what you are seeing is caused by the acid. With my NDE no hallucinogens were taken and I knew what I saw, heard, and 
felt was like no trip on acid ever taken. For me, it was my trip to the light-a very real voyage in itself.

Getting back to the background, I graduated to barbiturates, heroin, and cocaine by the time I was seventeen. For the next eighteen years, I continued doing cocaine, heroin, barbiturates, and methadone. When I was twenty-two, living in Florida and married to a fellow addict, I enrolled in a methadone maintenance program that I faithfully remained on for a little over twelve years. Accompanied by pain pills, Valium, heroin, and coke. The partying days of drugs turned into the longest days. Month after month, year after year, the cycle was vicious. Being both mentally and physically addicted was a bitch.

When I was seventeen, I had my first conscious overdose from heroin. Walking up four stories to a Bronx rooftop [and] looking down to the street was my remedy of revival to get air, for my friends were too high to take me to a hospital or to inject salt or speed or cocaine. Those were the things to do ... to get me back to life.

As a senior in high school, I had a bad barbiturate overdose resulting in a six-week stay at South Oaks Hospital for withdrawal. After leaving, I only started to get physically strung out again. Until my late twenties, twenty-eight to be exact, I didn't even attempt to stop, for I didn't think I had a problem. It wasn't until I separated from my ex-husband that I figured I'd try to get off everything and stay just on methadone that I entered my second hospital ten years later [i.e., when she was twenty-eight], only to find out they substituted for the drugs other "prescribed drugs." I had a vacation from coping.

Still addicted to the prescribed drugs when I left the hospital, I continued my dreary life. I went to college at Dowling for four years, not straight a day. Majoring in social work led me to believe I could figure out my problem. In my last semester, I slipped on a puddle of water and got a concussion, threw out a vertebra and continued my devastating life. Both mentally and physically I was in a lot of pain. By the way, at this time, overdosing had become a thing of just blacking out; or having my receptors overflow; or having my system let go of all fluids; or turning colors. It was no big thing-everyday life to me.

In the past three years from June, 1985, to March, 1988, I detoxed four times. In 1985, I gave up crack, remaining on everything else, and to let you know the progression of addiction, I was taking a hundred pills a day, including the other drugs. In 1986, I was to be administratively detoxed off the methadone program because of my failure to stop doing all the other drugs, so I went to Harris Hospital which is in Upstate New York, where I met Diane Norton. I was in such bad shape in that hospital, it was "sad to say." This was the only time and the first time I saw and realized how addicted I was. The average stay is 5-7 days. I was there for 27 days. I left the hospital still unable to sleep for the next two weeks (that's for 27 days and two weeks, no sleep). I shuddered and shook for the next two months. I felt so bad I couldn't allow myself to be in a normal environment with access to doctors for drugs and the illegal ones, too, so I put myself in Rehab for three months.

I left Rehab and got my first job in thirteen years driving a school bus. After a couple of months out of Rehab and three months there (all 
straight) I had a bad accident, totalling the bus. (By the way, no one else was on the bus.) I threw out my neck and back pretty good. The doctor gave me pain pills and, believe it or not, that triggered my old patterns and within weeks, I was back to square one.

Now it's July, 1987, and I saw how after three months of abuse how bad I had gotten to detox again. As the doctor said, "There's only so much we can do." After twelve days in the hospital, I was discharged in bad shape. At this point relapse was inevitable.

Then, in October of 1987 is when I had my near-death experience. I went into the Bronx with a friend. Already high, I proceeded to shoot two bags of heroin mixed with some cocaine I had with me. After having it injected into me, I was really wacked out. I went out for the count. I had always told this friend that if ever I overdose, do not take me to a city hospital for fear I would die there. Instead take me to Good Samaritan Hospital on Long Island.

As if God knew, which he did, that is what I wanted, only to grant me my last wish. This is when after countless overdoses, I overdosed forty minutes later. I vaguely remember being carried into the house, and when there, trying to be revived with water, ice, and slapping of the face. Now is when the NDE begins its journey to the light.

I was lying down on the floor of his grandmother's room. At this point, his mother, having seen me as I was, had called the paramedics. They stormed in.

I was out of my body perched on a bookshelf like a little elf. Really, I felt like a little person looking down on this left-behind body. As I looked down watching my physical body turn purple, blue, and then gray, I remember saying to myself in my out-of-the-body self, "This time, Pat, you really did it." There was a part of me, like a sixth sense, that knew this time you really are dying after countless times of coming so, so close. I knew what was happening and with such amazing awarenesswatching myself from above still smaller only to see and hear all the paramedics work on me with IVs. I still remember 2 IVs, 2 IV shots of Narcan [and] at that time, I said to myself, "Narcan-that will get me out of my dope-induced coma with no problem." [Yet], a part of me even at that point felt it wasn't time to come to yet, or to get back into this earthly reality. A part of me knew and I felt I had "places to go and things to see." Although I had no idea of what to expect, for I never knew anything about NDEs, yet I felt there was more. It was like going through a revolving door and knowing you can't stop along the way, for it wasn't finished revolving.

I'd also like to mention the fact that my memory went with me into my trip to the light, for otherwise how would I have known that Narcan would bring me out? Trying to revive me and my heart using a defibrillator, I heard them say on the telephone to the hospital, "We're not getting a pulse; we're losing her." I wasn't even upset that I was dying because the next thing I remember happening was that I was floating away.

I was no longer the little elf on the shelf just watching. Now it was me floating in a dimension of total peace and serenity. What a feeling, better and not comparable to any drug-induced or not drug-induced feeling I had ever known. I was floating in a mist that was below me, a sort of fog 
above a pasture-type setting. I kept rising and moved upward and toward the brightest light. The light was the brightest and most brilliant I had ever seen both before my NDE and since. The light was more brilliant than a diamond. In fact, it was a whitish-blue color. Again my memory was with me, for how would I know to differentiate the colors? The light was sharper than the light of any star (for astronomy is my hobby).

I kept going toward the light and when I was about two-thirds of the way there I had a multi-dimensional sense, a feeling of seeing my leftbehind body, having my past life flash in front of me, and at this point seeing stairs. Or at least to me it was like gigantic stairs-or rather levels of some outrageous and beautifully landscaped city. This part of my NDE is vague. The only way I can best describe it is that it reminded me of a castle. I only got so far and then the trip to the light ended at the bottom part of this plateau castle. The scenes of my life kept flashing before me, scene after scene, event after event zipped by right in front of me. It was like watching a movie without the projector and screen.

This all happened so fast, yet being dead for almost three minutes doesn't seem time enough for all the events to have happened. The timing is so slowed down that I felt like I was there for so long. Even just the floating forever onward and upward seemed longer than three minutes. Only afterward did I think of the amount of time. During the NDE, it was an eternity in itself.

Then just as $I$ felt I found the feeling of total love, acceptance, and peace and serenity did I feel that I was being told that I had to come back, there were things I still had to do.

All of a sudden, I jolted back into the physical left-behind body, flopping like a fish. When I say jolted, I mean just that. It felt like a jolt, and with that crash, [it was] sort of like I hit a brick wall when I came back into my body. Because once all that energy or whatever got into the only place to go, it was like the top was closed off and still all this energy [was] racing around.

My initial reaction was: "What's this?" I realized I was back on this earth, alive. I figured I should be overwhelmed, yet I wasn't. I was pissed off at having to be back. I didn't have any verbal words when I went to the light, but I do know that I was forgiven for all the wrongs I had done and the thoughts and feelings turned into words before I was to return. I was returning to "hear" and, more important, to feel that I . . still have things to do.

When I came to with such a jolt, [it] made me so aware of the difference between this world and the world of the light. I wanted so much to go back, but in my heart I knew that any way except the way I am to go is not what my God has ready for me in the realm of such total love.

In March of this year, I finally got myself together. I am a recovering addict that unless you knew me before, you would never know that I had such a life of despair.

I am now a happy, good-hearted, honest, wholesome person. I have this inner peace about me that is incredible. I attribute the way I am now to my NDE.

Since my NDE, I am pretty psychic. I seem to know so much more than before. Nothing that happens seems to amaze me. It's so much a part of 
me that sometimes I do take it for granted. I am so aware of things, people, and animals. Anything that is a part of this universe I feel so connected to, from trees to stars. I have a special interest in astronomy. I find great pleasure with natural things in my life. I go with my vibes which never get me in any type of trouble [but] instead make me more confident and reassure me of what's right.

Also, since my NDE, I seem to know what is going to happen. At night when I go to sleep, I dream these dreams that to me are sometimes more than a dream. I dream normally-don't get me wrong-but sometimes I go places, and in these dreams I see things that happen later on. For example, I went off in a dream and this was more than a dream. I saw the plane crash that happened in Germany when the plane crashed into the audience full of people. I knew I was in a different country because of the architecture. Afterward, I told Diane about it and what it entailed. I knew I would hear about it, and, sure enough, a few days later, I saw it on TV-just as it happened in my dream.

Sometimes it doesn't take days. I get visions of something minutes before it happens. This happens to me while I am awake. I'll go somewhere and know what the room looks like. It's not déjà vu because that tunes in as it happens. I do get them, too, and I can zoom in to the exact night I dreamt the event.

Well, anyway, I am getting writer's cramp, and I just wanted to say before I end this letter that I know a lot of things I have just told you are hard to believe. Everything I wrote from page one to now has been to tell you about me before my NDE, during my NDE, and after my NDE, and how the NDE has changed me in this life in countless ways. This had to be a long letter to cover some of the events in my life. Thanks for reading it.

Due to the Light, I remain Happy,

Pat

\section{Bob Helm}

One day I received a desperate phone call from one of my friends who works for Canadian television. Did I-she prayed that I did-know a Canadian NDEr in the Toronto area who had a really compelling experience of the sort that would "wow" the Canadian masses? After emitting my usual groan (how often we near-death researchers have heard this urgent query from our colleagues in TVland!), I actually did scan my mental files for such a possibility, but came up one short of the desired number. Still, in my best earnest voice, I promised that I would give it some further thought and call back if I could think of a suitable candidate.

The next day a letter from the perfect candidate arrived in my mailbox. 
Dear Mr. Ring,

I very much enjoyed your book on the near-death experience. It is a great service you are doing, bringing these transformational experiences to public light. Not so long ago my life was completely turned around by one of these and had it not been for the book, Life After Life [Moody, 1975], current at the time, I might still be wondering what in the world (or out of it) had happened to me. Somewhere in [Heading Toward] Omega [Ring, 1984] you say you never tire of hearing about these experiences, so I am encouraged to offer you mine. In any event, it has been most enjoyable writing about it again. When I first recorded it, shortly after it occurred, the account was emotional rather than descriptive. A present-day edition follows:

On the 7th of November, 1979, I was scheduled for surgery on my leg. It had been broken in an automobile accident years before, and set badly. As a result, the knee joint had been wearing unevenly, giving me a great deal of pain. This was slight, however, in comparison with the enormous amount of both mental and physical pain I had been experiencing for many years; for I had been an alcoholic for most of my adult life, recovered for over a year at this point. My life had been a repeating pattern of self-destructive behavior and depression, the withdrawal experience of the past year dreadfully painful and dark.

I had a premonition I was to die during this operation. The feeling was so strong it was almost a fact in my mind. The surgeon had given me several opportunities to cancel: the date had to be changed, the operation was not essential, etc., etc.; but for some reason I could not fathom I was absolutely determined to go through with the procedure in spite of my fear, and I did so. I was under general anesthetic for the surgery, an osteotomy, lasting almost 5 hours.

I woke up in the recovery room, saying out loud over and over, "I must remember, I must remember." I was desperately ill from the anesthetic, but to my surprise my spirits seemed higher than they had been for many years. The nurse asked me what it was I had to remember, and I could not tell her. This statement absolutely desolated me, and again I was surprised by my reaction. She asked me how I felt, and I said terrific, to her utter astonishment and mine. As I was wheeled on the gurney along the corridor to my room, I tried to no avail to recall what it was I needed to remember so urgently; and I could not. The feeling of loss was overwhelming.

But then, as I absently watched the ceiling above, in a flash, memory began returning to me. The ceiling lights had triggered recall of the most important, vivid, real experience of my life. It returned to me in waves of joy, and I was awe-struck by the memory. It was all so real, and so important; and so improbable!

I had been trained in technology. I had a natural aptitude for the sciences and mathematics, disciplines based on logic. A childhood faith in some sort of Divine Father had been eroded by alcohol and materialism very early in life, and my logical mind would not accept what it could not rationalize. Yet here I was in a hospital, reliving the most important experience of my life, something that had occurred during unconsciousness; and I had never experienced anything more real to me than this. I 
did not tell anyone about it at first, because I feared I would be thought insane. Eventually I told two or three of my best friends, also individuals trained in logic, and they dismissed the episode out of hand as an hallucination, in spite of my protestations. I eventually told my wife, who was the first to believe that something extraordinary had happened to me, though we were both at a loss to explain it. This is how I remember it:

I was in a tunnel, traveling at enormous speed toward a light, which was incidental at this point. I had flown frequently on business, and participated in automobile racing at one time, and I was aware that the speed I was traveling was far in excess of anything I had ever experienced, and it was increasing all the time. The walls of the tunnel were a blur, but as I looked more carefully I came to the realization that this tunnel through which I was traveling at such unbelievable speed was composed of planets; individual solid masses blurred together by speed and distance. Incredibly, I seemed to be hurtling through the universe!

There was tremendous sound, too. It was as if all the great orchestras in the world were playing at once; no special melody, and very loud, powerful but somehow soothing. It was a rushing, moving sound, unlike anything I could remember, but familiar, just on the edge of my memory.

I was suddenly frightened. I had no idea where I was bound at such speed, nor had anything in my life prepared me for this adventure. As soon as I realized I was afraid, a presence reached out to me; not physically, but telepathically. It was a calming, gentle presence and a voice, which said, "Take it easy. Everything is O.K. Relax;" and this thought transference immediately induced a soothing effect on me, far more powerful than anything within the experience of my stressful life.

I had been traveling toward the tremendous light at the end of the tunnel; but just as I was about to enter it, everything went black. When I close my eyes in a dark room, I still have the sensation of sight. I also retain a sense of touch and feeling, of having a body. The black of which I speak was total, absent of any sensation. My consciousness simply WAS. I existed, but without any senses whatsoever. It was absolutely terrifying. This lasted but a moment, as had the entire journey. Then sensations began slowly to return, and I understood that these were positive only. There was no longer pain in my leg, nor any physical or mental discomfort or unrest, where before there had been chaos. There was instead peace and joy and harmony and light. Oh, what a Light it was! As I became increasingly aware of it, it was gold and silver and green and full of love. As the sensations solidified, and this seemed timeless because there was no hurry in this place, I became aware of a being sitting beside me. He wore a white robe, and exuded peace. He was the one who had comforted me during the latter stages of my voyage, I knew instinctively. He was comforting me still. I knew he would be all the friends I never had, and all the guides and teachers I would ever need. I knew that he would be there if ever I needed him, but that there were others for him to look out for, so I needed to care for myself as much as I reasonably could.

We sat side by side on a rock, overlooking the most beautiful landscape I had ever seen. The colors were outside my experience, vivid beyond my 
dreams, the composition exceptional. It was exquisitely pleasant and there was no pressure, for my friend knew me and loved me more than I could ever know or love myself. I had never felt such radiance and peace. "It's really something, isn't it?" exclaimed my friend, referring to the view. I sat comfortably with him and admired it, uncharacteristically silent. He said, "We thought we'd lost you for a while." We were on an island, overlooking a wooded, rocky bay. The waters were bright with a living quality I had never seen in years of recreational boating. The trees were magnificent, each outlined in its own light. The mountains in the background were stately and calm, each with an indescribable aura.

My first reaction to this amazing sight was awe mixed with fear, but it finally occurred to me to ask where I was. My friend said it was rather difficult to explain; but that they wouldn't be needing me for a while "back there." This puzzled me and I asked if I were dead, and he said I certainly was not, but that I might like to look around when I felt like it. I was more than content to sit for a while, and did so. It was very restful. Then, as I studied the landscape, a lifetime interest in photography prompted me to think that the landscape I admired so greatly would be even better balanced if a certain mountain was repositioned to the other side. Immediately it moved to where I had imagined it! It was difficult at first to believe, but the experience was more real to me than anything on earth, and I knew it had happened. Then, as I puzzled over this, I wondered if I could move it back, and it immediately shifted accordingly.

About this time, while I was still marveling over what I had seen, my friend suggested we might be on our way; and becoming restless myself, I agreed. IMMEDIATELY we arrived at another location, on a beautiful street. We appeared to be alone there, except for the street-sweeper, who was responsible for the spotless condition of the place. Here again, the colors and textures were outside my experience; and the road and the sidewalks appeared to be paved in some kind of precious metal. The buildings appeared to be constructed of a translucent material. I felt prompted to talk to the street-sweeper, and congratulated him on his efforts. He said work was a joy to him, and he derived his pleasure from doing the best job he could at all times. This statement nonplussed me somewhat, for I had never been enthusiastic about what I considered menial tasks. This man appeared absolutely sincere, however; and I was very impressed by his industry and the obvious love and care he brought to his work. While I was thinking about this remarkable fellow, we relocated again, INSTANTLY.

This time we were audience to a choir of angels singing. Angels were totally outside my reality at the time, yet somehow I knew these beautiful beings to be angelic. They sang the most lovely and extraordinary music I had ever heard. They were identical, each equally beautiful. When their song was over, one of their number came forward to greet me. She was exquisite and I was mightily attracted, but I then realized my admiration could only be expressed in a wholly nonphysical manner, as to a little child. I was embarrassed by my error, but it did not matter. All was forgiven in this wonderful place.

Instantly we arrived in an art gallery. It contained the work of the great masters of all time and all places. The display was both classical 
and modern. Some of the great works seemed familiar. Others were unlike anything I had ever seen, indescribable. The beauty and form of the sculpture and paintings on display were beyond words. A lifetime could be spent in this place, but to see everything I needed to see during this visit, we must move on.

Next we materialized in a computer room. It was a place of great activity, yet peace prevailed. None of the stress of business was present, but prodigious work was accomplished. The people seemed familiar to me, like old friends. This was confusing, because I knew there to be present those who lived on earth still, and those who had passed on. Some of them I knew by name, others by reputation; and all had time for me, to teach me if ever I need help understanding. One of them was Albert Einstein, whom I had always admired greatly but distantly, and this great man took time away from his duties to encourage me. He asked me if I would care to operate the computer, which was very complex and beautiful and designed to guide the path of destinies. I was flattered, but felt incompetent and unsure of myself in the presence of such greatness. I told him I would like to try, but I was afraid of making a mistake. He laughed gently, and reassured me, saying that error was not possible in this place. Encouraged, I seemed instinctively to know how to operate this unusual machine, and waved my hands in a pattern over the large keyboard, rather like playing a piano without touching the keys. I knew instantly the task had been performed perfectly, and it had somehow been of great benefit to someone. I was suffused with the joy of a job well done. I would gladly spend eternity here at this rewarding work if only for the tremendous feeling of well-being I had experienced as a result.

We continued our tour and arrived at a library. It was a vast old traditional building, containing all of the wisdom of the ages, everything ever said or written. Room upon room, shelf upon shelf of books stretched away as far as the eye could see. By this time I had growing doubt I was destined to stay in this mysterious yet familiar place, even though I knew in my heart it was home. I had the uncomfortable feeling I must return soon to resume my life. My guide, for by now I thought of him as such, told me I must study and learn from the infinite array of wisdom before us. I was dismayed, and said there was no way I was capable of such a task. I was told to simply make a beginning, to do the best I could, and that would always be good enough. There was plenty of time.

The feeling I must leave had grown into certainty and dread. My apprehension was confirmed when my guide told me plainly that it was time for me to go, but I should remember that this was always my home, and I would return some day soon. I told him it was impossible for me to go back to the life I knew after this experience; but he said there was no choice, I had work yet to do. I protested, saying the circumstances of my life were such that I could not continue; and I was filled with consternation at the thought of facing the mental and physical pain I feared would lie ahead. I was asked to be more specific, and I recalled an area of my life in which I had experienced difficulty. Instantly I was filled with an overpowering sense of that specific emotion. It was almost unbearable. Then, with no more than a gesture, the pain was made to vanish, to be - 
replaced by a glorious sense of well-being and love. This process was repeated several times, with specific areas of my life where I had been experiencing difficulty. My friend then pointed out that I could perform this astonishing feat myself. It was not at all difficult, he said, and I would have an opportunity during the balance of my life to practice, and to make a beginning learning about some of the other things I had experienced during this journey. I was still dismayed, but I was given to understand that there was to be no argument about returning. Rules were rules, and I must abide by them without fail. There were to be no exceptions made for me, and self-pity was not an acceptable form of expression.

In an instant, it all vanished, and I found myself in the recovery room, wondering aloud what it was I was to remember. The experience might have lasted 5 minutes or 5 hours. There was no sense of time at all, and I could not understand this for many years, for my life had always been impatient and hurried.

The effect of the experience on my life was immediate and electrifying. I knew this as a turning point but I had not the slightest idea why, or what had occurred. I was tempted to attribute the experience to hallucination, as my friends had all suggested. Somehow, I could not dismiss it so easily, even though it might be the easy way out. I was immediately motivated to write about it, and about other events in my life. I was filled with a great longing to go back, and knew this planet was only a temporary home for me, though this made no sense at the time. My life was to change radically, and continues to unfold in unforeseen ways to this day.

Following the stay in the hospital, I had arranged to recuperate at home. I had a TV set in my bedroom, and watched my favorite programs. To my amazement, they no longer held much fascination for me. I found myself able suddenly to discern truth. I found this quality present in such things as the documentary programs found on PBS, and the Canadian equivalent; and in programs featuring certain spiritual issues. The latter had actually been repellent to me, and this development made no sense either. I was driven to get to the bottom of what had happened. What could have precipitated such an immediate and unprecedented change, and caused such inner conflict?

My wife was working full time, fatigued by the strain of looking after a bedridden husband and the household too; but I prevailed upon her to make a special trip to the library by taxi to see if she could locate something to explain the mystery. Books had always been my friends, and I suggested she begin with the "Unusual and Unexplained" section. I had seen it often enough, but rarely availed myself of its contents, preferring the distraction of fiction. She returned with two shopping bags full of pocketbooks, selected because of their economical size rather than their content. For weeks I rarely slept. One of the first books I was inspired to read was Life After Life [Moody, 1975], written by an M.D. who had researched near-death experiences; and it was reassuring to know that I was not alone. The Edgar Cayce material fell under my scrutiny too. Later my wife and I would join a study group based on this 
material, but this was further down the path. The near-death experience is now part of a much greater perspective brought about by a dozen years of spiritual study, prayer, and meditation; and it is quite a different world I see now through the same eyes.

Subsequent investigation unearthed the fact that the experience had been triggered by a momentary cardiac arrest under anesthetic, though the doctors were reluctant to admit this until pressed. The operation was concluded in the absence of my spirit, or soul, I now understand. I am also aware of the symbolism of the events in the experience, and have encountered many of them consciously. There was no sense of time in the experience, and that is impossible to convey in words; nor can words adequately express the joy and peace and light of our spiritual home.

$M y$ wife and I retired from the city a few years after the NDE, and now live quietly in a home on the edge of a forest, where we publish newsletters based upon the sharing of spiritual material, and maintain an extensive correspondence. It is far different from the pressures of urban life. The work brings us both great satisfaction, and we have radically altered our thinking and lifestyle; I more so than my wife, who accepts the whole business far more philosophically and patiently than I might have done if the circumstances were reversed. There is much more to tell, but the core of the experience is covered. Death holds little fear for me now, and I know myself and all humankind to be spirit, clad temporarily in body, here on earth to learn and grow. Those who remain in spirit are available to us, to help us along the path. All we need do is ask.

Thank you for sharing my tale. Incidentally, I fit well within the norm of data for NDErs presented in your book. If I may be helpful in any way, please be in touch without hesitation. We are told that if we help one single soul up the ladder while here on earth, our lives should be rated a success. You should be very pleased at what you have accomplished. Thanks on behalf of the many, including myself, who have grown from your work.

Very best wishes, Bob Helm

The combination of Bob's story, his offer to help "in any way," his proximity to Toronto, and the remarkable timing of his letter forced my hand to the phone with alacrity. "I think I have someone for you," I told my friend.

When the arrangements were made, it turned out that Bob had apparently worked for the Canadian Broadcasting Corporation at one time, and that the director of my friend's program had known many of Bob's former colleagues there. According to Bob, "we all had a great time" and his on-camera return to the world of Canadian TV was thoroughly satisfactory, though he confessed that it was much easier to write about his NDE than to talk about it! 


\section{A Personal Conclusion}

Writing this article for the tenth anniversary of the founding of this Journal of which I had the honor of being the first editor has put me in a reflective mood. Images of the exciting early days of the establishment of the field of near-death studies have been flitting through my mind, along with those of many of the persons, researchers and NDErs alike, who played a role in all this. And, perhaps because anniversaries are occasions when one looks back at the past and takes stock of the present, I have been led to think about my own history in and relationship to this field. I have been exploring, studying, wondering about, and writing on NDEs for nearly a decade and a half now, and in the course of working on this article, it has come to me that I have reached the point where I have need to say no more on the subject. That is why, taking a leaf from James Hillman's books and his love of double entendres, I have deliberately entitled this section "A Personal Conclusion." By this phrase, as you will now understand, I mean to indicate not only that I would like to express some of my own personal views on what I have written about here, but also that this marks a personal stopping point for me on the endless trail of the NDE. At the time of this writing, I am also finishing up the manuscript for a new book, The Omega Project, which will deal in part with NDEs, and when that's done, I intend to devote myself to new pursuits and explorations.

I don't know exactly what it was about writing this article that brought home to me the fact that my work in near-death studies was now concluded, but I am inclined to believe it had something to do with the depth of insight as well as the extended character of the accounts I have quoted here. In my previous work on NDEs, I have always given a central place to NDE reports because they are, rightly, the foundation for every idea that we researchers offer about these experiences. Never before, however, have I devoted such a high proportion of my allotted space to these narratives. Why now? I think it is because, if I were to give a final summation of the essential teachings that NDEs represent, I would want, as much as possible, to speak in the voice of NDErs themselves. In fact, I consider my role in near-death studies to have been little more than to serve as a kind of channel through which such persons-those who do not write books or articles-could reach a wider audience. The four accounts I have presented here allow me just to stand aside and, addressing that audience one last time, ask simply, "My friends, do you understand?"

Everything of importance that I have tried to bring out in my writing and speaking on NDEs is to be found in these narratives. If you have 
read them carefully and absorbed their implications, you scarcely need to read anything else on the matter. Of course, in a proper conclusion to this paper, I would discuss the evidence for the providential character of these experiences, their sometimes obvious symbolic character (to which Bob Helm himself makes an allusion), the way in which they reflect the deepest yearnings of our soul, and their incredible power to stay the hand of perdition and restore hope and purpose to seemingly ruined lives. But isn't this all virtually self-evident? Do I need to find still another way to tell you that Auden's cry is answered by the NDE and that Marguerite's salvation is no mere literary convention?

\section{Amazing Grace}

Now, you would think that my return to that phrase would and perhaps should mark the real end of this paper, but the fact is that I have another surprise for you: a coda of sorts and one that is almost demanded, as I think you will agree, by the logic of this confessional conclusion. As I take my leave, an NDEr must, of course, have the last word.

\section{Göran Grip}

In the summer of 1989 , I was a participant in an international NDE congress in Norway and while there, I encountered a remarkable young man, a Swedish physician named Göran Grip. The translator of a number of books about NDEs into Swedish, Grip had had an NDE himself as a child, though, as he will tell you, he came to realize this only in later life. In Norway, Grip gave several presentations, all of exceptional interest to me, but the most memorable by far was his rendition of his own NDE, as he now recalled it, and the meanings he ascribed to it.

I was delighted when I learned that Grip would be attending the IANDS Washington conference in 1990 (already mentioned in connection with Beverly Brodsky and Lorna Stephens) and looked forward to seeing him again. I did have a chance to talk with him privately, but before that I made a point to attend a workshop he was giving in which he again referred to his NDE and how he was able to draw on its lessons in his own medical practice.

I do not know that much about Grip's childhood and background, but his face shows that he is no stranger to suffering and he speaks with 
the quiet authority of a man who has spent a great deal of time in selfreflective inquiry. I couldn't help being aware, almost immediately after his beginning to speak, how still the room had become, as if all members of his audience had found that place within themselves that resonated with Grip's own center. Not in his personality-which has touches of a wry and sprightly humor, by the way-but in his effect on an audience, he reminded me very much of Elisabeth Kübler-Ross, another physician whom he clearly esteems and whose work he has also translated into Swedish.

Subsequent to our meeting, Grip was kind enough to send me a copy of a statement he had written concerning his NDE, and it is with a portion of his testimony that I conclude this article. More than anyone else I have quoted thus far, Göran Grip reflects on the meaning and the essential mystery of the NDE. As both a physician and experiencer, he can see it from both the scientific, external perspective and from the standpoint of his own private understanding of it, and what he says about "his theory" about the NDE is most instructive.

In his commentary, Grip says some things that may surprise, perhaps even shock you, especially in view of all that has gone before in this article. Yet, rather than take exception to his words and worldview, I think it is better to see how the NDE compels no final truthexcept one's own.

Finally, Grip will let you on what he calls the big secret. In my opinion, it has to do with what may be the only universal in the NDE, and the most important lesson that we can all glean from our contact, whether personal or indirect, with the world of the NDE:

It was not until I read Life After Life [Moody, 1975] that I realized that I had had an NDE. I recognized almost everything Moody wrote about the NDE. At first I thought that I read about it before, but I soon realized that my recognition was on a far deeper level than intellectual recognition. I knew what it felt like to have an experience like that. With the help of his books and, later, Recollections of Death by Michael Sabom [1982], I was able to revive more and more details of my own experience, and I understand that what had been half asleep in my memory for so long was no less than an NDE. However, no matter how much I scrutinize my memory I have to this day not been able to put date and external circumstances to my experience. The closest I can come to it from this point of view is that it must have taken place early in my childhood.

Seen from the outside, however, I don't know of any instance where I have been close to death. But I have been through two minor operations as a child, and both times I was put to sleep with ether. My own guess is that I had my experience during one of these operations when I was about five. I have found the medical records from one of them, and it reports only a completely uneventful hernia operation. 
My experience consists of three parts and, again, within my memory there is no connection whatsoever between them. But in the light of what an ordinary NDE looks like, they make perfect sense as three parts of the same experience. ...

My last memory is the greatest and most important one. I was in a place where everything was light around me-something like clouds and still not clouds the way you see them from an airplane. I was standing at the bend of a road of light leading to something at a far distance that it is not possible to describe straight out.

But with a poetic adult image I could say that it was not a town wall, and behind it was not a town. In the wall there was no gate, and that gate was closed and locked. I was not to go there, and that didn't matter.

In front of me, on the road, was a being of light, a presence rather than someone visible, a light in all the light. I immediately realized that this being could see right through me and reveal my deepest secrets. My very first impulse was to hide, but I realized immediately that this would not be possible-and also not necessary. For between us I now felt a strong mutual wordless love, and I knew beyond any doubts that whatever he would see in me, he would understand and accept.

His love encouraged me to go through my life up to that point. I saw, relived, remembered things that had happened in my life: not only what actually took place but also the emotions involved. Being five years old you haven't had the opportunity to commit many bad things, but I had a two-year-old brother of whom I was very jealous, and a lot of times I had been mean to him in the usual way between brothers, and had been punished in the usual (non-violent) way between parents and children.

Going through what had happened between us, my focus was not on what we actually did to each other (or "who started"). The emphasis was all the time on our exchange of emotions. And because of the love and understanding radiating from the being of light, I found the courage to see for myself, with open eyes and without defenses, what in my actions and feelings made my brother happy, and what caused him pain. And for most of the episodes we went through the being offered me an alternative way to act: not what I should have done, which would have been moralizing, but what I could have done-an open invitation that made me feel completely free to accept or not to accept his suggestions.

I knew for sure that if I would accept his suggestions he wouldn't become triumphant, saying: "Goooooood boy," and if I turned down his suggestions he wouldn't sulk or try to talk me into changing my mind. I felt totally free and respected. Needless to say, his suggestions were all for a more loving and understanding attitude.

The way we went through the episodes was much like the way you go through things in your own mind: in a wordless way you simultaneously relive something as if it happened once again and watch it from above seeing yourself as an actor among the others; only this time we were two beings seeing the same things at the same "moment."

Time was not passing in the usual manner. The episodes of my life were not replayed like a movie. An entire episode-with its beginning, its middle and its end-stood out as an entity: it was possible to see simul- 
taneously every little action or spoken word with its emotion (his or mine) tacked to it. With an adult description it was as if we were able to wander about, back and forth, in a static landscape the features of which were not trees and hills, but actions, words, and emotions. His suggestions were there at the same "time"-as an alternative landscape superimposed on the original one. And although I re-experienced envy, hate, humiliation, loneliness once again, this time it was flooded with his love and the strength it gave to me.

On the other hand, there was a kind of ordinary time lapsing in my wordless communication with the being.

The being had no physical features except for the light. Nevertheless he was quite definitely male. To put a name on him - God, Jesus, Smith would be utterly meaningless. Although he was far more powerful, wise, and loving than I ever expect to become, he was not superior to me. For on the deepest and most important level of them all-the level where we loved each other-we were equals. Thus "him"- not "Him." And thus no praise, no worship.

This hasn't made me think that I am superior to other human beings. On the contrary, the lesson is everybody is equal to everybody else when it comes to real love-irrespective of age, sex, education [etc.].

The patient who gets the first and last word in Recollections of Death [Sabom, 1982] puts the proper label on my experience: the big secret-the big secret that I was unable to tell my parents about, the new knowledge that I tried to show them, but which went unnoticed by them.

Maybe the most important part of the big secret that I was able to bring back and compare to my real life is this: real love between two people (any two-irrespective of age and sex) is always a mutual feeling. The two of you know at all times that you love each other. Love is not a feeling that you carry within-it is what is passing back and forth between the two of you.

Love is nothing that just comes flying from above, however. It is rather something that you have to build together, nurture, and defend together.

When love leaves you, you know it immediately. If you have the courage, you realize this, act accordingly, and face the pain. If you don't this is the point where you start lying to yourself.

Whenever the feeling is not mutual it is not love but something different: possessiveness, jealousy, sex, hate, depression. Love is the bridge joining the two banks separated by the river. Each end of the bridge is firmly attached to its bank, enabling communication in both directions between the banks. When it is only attached to one bank, its other end is hanging loose; it is no longer a bridge. It is only a jetty.

I could say a lot more about the big secret, but I stop here for this time. I am not religious, I don't believe in God, and I never go to church with its empty rituals and dogmas containing only vague and distorted reminiscences of the real thing.

Also I have never been interested in parapsychology.

I don't know if my experience changed my life, or if it gave direction to it in these early years. I didn't have much of a life before the experience to compare with.

I have no theory about the NDE. The fact that I have had one myself 
gives me no advantage in trying to explain it, scientifically or otherwise. And this is so for the same reason I can't explain ordinary physical vision only because I can see. The only advantage I have from my NDE is that I know the experience exists. I know that other people's NDEs are no more [and] no less "invented" than my own.

Whatever the explanation to the NDE will turn out to be, it will provide us with significant information about ourselves-our true nature. This knowledge will hopefully have an impact on how we treat each other not only within the medical care system but in the society as a whole. And whatever the explanations will look like, they are sure to be exciting and revealing.

But there are of course two sides to an NDE: the scientific one and the experiential one-the outside and the inside. For me who has had the great fortune of having had an NDE, from the "inside" no explanations are really necessary. They can neither add to my experience-nor reduce it. It is as if you had a nice dream where you find a lot of golden coins. Then you wake up and feel sorry that it is over. What a loss!

But in the next moment you discover that you still have all the golden coins that you found in the dream. Was it only a dream, then? Actually, it doesn't matter what it was. The only thing that matters is that the golden coins are good money, and that with it you can buy Real Things.

\section{References}

Grosso, M. (1985). The final choice: Playing the survival game. Walpole, NH: Stillpoint Press.

Harris, B., and Bascom, L. (1990). Full circle: The near-death experience and beyond. New York, NY: Pocket Books.

Moody, R. A., Jr. (1975). Life after life. Covington, GA: Mockingbird Books.

Ring, K. (1980). Life at death: A scientific investigation of the near-death experience. New York, NY: Coward, McCann and Geoghegan.

Ring, K. (1984). Heading toward omega: In search of the meaning of the near-death experience. New York, NY: William Morrow.

Ring, K., and Rosing, C. J. (1990). The Omega Project: An empirical study of the NDEprone personality. Journal of Near-Death Studies, 8, 211-239.

Sabom, M. B. (1982). Recollections of death: A medical investigation. New York, NY: Harper and Row. 